Relations industrielles

Industrial Relations

\title{
Broadcasting Labour Relations
}

\section{Bernard Brody}

Volume 27, numéro 3, 1972

URI : https://id.erudit.org/iderudit/028312ar

DOI : https://doi.org/10.7202/028312ar

Aller au sommaire du numéro

Éditeur(s)

Département des relations industrielles de l'Université Laval

ISSN

0034-379X (imprimé)

1703-8138 (numérique)

Découvrir la revue

Citer cet article

Brody, B. (1972). Broadcasting Labour Relations. Relations industrielles /

Industrial Relations, 27(3), 436-453. https://doi.org/10.7202/028312ar

Tous droits réservés (C Département des relations industrielles de l'Université Laval, 1972
Ce document est protégé par la loi sur le droit d'auteur. L'utilisation des services d'Érudit (y compris la reproduction) est assujettie à sa politique d'utilisation que vous pouvez consulter en ligne.

https://apropos.erudit.org/fr/usagers/politique-dutilisation/ 


\section{COMMENTAIRES}

\section{BROADCASTING LABOUR RELATIONS}

\section{Bernard Brody}

This paper ${ }^{1}$ began as a typical book review of an essentially academic study of the labour relations system in Canada's broadcast industry. Once under way, however, it became rapidly apparent the endevour would go far beyond the traditional limits of the task ${ }^{2}$. Among the events analyzed will be a detailed view from within, a personal perception of the 1959 CBC-TV producer's strike.

Ruby Samlalsingh's Broadcasting - An Industry Study ${ }^{3}$, is a highly competent piece of research on one of the most dynamic and controversial sectors of the Canadian labour scene of the 1960's. The author has made very fruitful use of the now-classical, Dunlop ${ }^{4}$ model with its well-known « contexts » «web-of-rules », « actors », «Outputs » and «Inputs ».

One of the major drawbacks of the book, acknowledged by the author in her Preface, is that several key issues were on the verge of settlement as the study cut-off was made. Among others, the IATSE/SGCT/ CUPE rivalry was in full bloom

BRODY, B., Assistant-Professeur, Département des relations industrielles, Université de Montréal.

* BRody, B., Assistant-Professeur, Département des relations industrielles, Université de Montréal.

1 The following abbreviations are used: IATSE, International Alliance of Theatrical and Stage Employees; NABET, National Association of Broadcast Employes and Technicians; ARTEC, Association of Radio and Television Employees of Canada; SGCT, Le Syndicat Général du Cinéma et de la Télévision; CUPE, Canadian Union of Public Employees.

2 The reviewer, currently assistant professor, Industrial Relations Department, Université de Montréal, spent twelve years (1954-1965) at the CBC-TV Montréal. He was personally very involved in two of the main events described in the book under review: the 1959 TV-producers' strike and the 1964 IATSE fiasco. He was a TV audio engineer and NABET shop steward from 1954 to 1958 and a TV coordinating producer and IATSE chief steward between 1959 and 1965 . He was also founder-president of the Montreal Radio and TV Employees; Credit Union in 1955.

3 Prime Minister's Task Force on Labour Relations, Study No. 1, Ottawa, 1970.

4 Dunlop, J., Industrial Relations Systems, New York, Holt, 1958. 
and the transformation of the Board of Broadcast governers into the Canadian Radio and Television Commission was yet to come.

\section{The Economic ENVIRonNement ${ }^{5}$}

In the section on the economic context, the author is overly restrictive in the concept of the demand for airtime (the «product» or « output 》). The purely commercial announcements ( 30 secs., 60 secs.) appears us the product demanded by advertisers. This approach reveals two weak assumptions :

\section{1 - that there is no demand for non-sponsored programs and}

2 - that program sponsors buy only the restricted, half-minute a fullminute of the actual product announcement.

The first point needs no further elaboration except to say that the CBC would certainly continue in operation if commercials were prohibited. Even without «commercials », the broadcast industry would still have important economic significance. On the second point, the advertiser who sponsors a program «buys » the entire half-hour or full-hour, and discriminates as to the type of program (content and time of broadcast) he wants to « vehicle» his product. Even purchasers of «spots $\$ 6$ are very selective not only as to which programs precede and succeed their announcements, but also the type of products advertised in the same station break. One gets the impression that the advertisor is only interested in the number of viewers watching his program (spot) in abstraction of the program content. In fact, the sponsor buys the whole program and is very concerned with the viewers' demographic qualities, as well as the purely quantitative ( costs per 1,000») dimension.

The author admits that the serious parcity of data on the private half of the industry placed severe limitations on her ability to give anything but the scantiest attention to this sector. This must constitute a serious shortcoming of the book since the private stations occupy half of the industry, and in terms of revenues, are growing at a more rapid rate than the CBC. It should also be pointed out that there is a marked tendency towards greater concentration of ownership as a few strong corporations procede to buy up stations. This trend will doubtless shape the future character of both commercial content and policy as well as program quality in this most potent of communications media.

We read (P. 12) «As far as the public is concerned there is no direct cost for this ... (TV) ... service $\gg$. While this is technically a true statement ${ }^{7}$, it could be misleading. The public does bear some proportions

5 The sub-titles are those used by the author.

6 «Spots are commercials which usually appear between programs, in the station breaks.

7 Subscribers to cable-TV do have a direct cost. 
of both program and commercial costs either in the form of taxes (i.e., CBC subsidies, now in the order of one million dollars per year) or for the latter, as a portion of the purchase price of the product. Though «...the cost is paid by firms 》 (P. 12), in the final analysis, this cost is shared by firms and consumers ${ }^{8}$.

The modern economist will also want to add to costs the value of alternate use of time spent watching commercials and programs. This factor constitutes a real cost in terms of the allocation (expenditure) of a very scarce resource.

\section{INDUSTRIAL RELATIONS}

The author makes several statements of opinion which really should have been footnoted as to source. "The private stations are reputed to be strongly against union activity ... ( reputed to have fought the union by threats of dismissal and demotion > (P. 35). The reviewer fully shares these opinions, and Miss Samlalsingh is to be commended on her research here too. Indeed the entire section on the actors (unions) is exceptionally well done and reveals her extensive ability. The cogent and accurate coverage goes well beyond mere description.

However, the addition of a new term « vertical unit \$ (P. 36 et seq) to describe an «industrial unit » is unnecessary and even misleading. The unit discussed - production employees - is in fact "horizontal ", the constituents being, in terms of the organizational hierarchy, on the same level, not on different levels.

On the following page (p. 37) the author offers this reviewer a splendid opportunity to comment on a widely-held myth in industrial relations. Some feel that we can eliminate all the work-jurisdictional frictions and inefficiencies by simply lumping the various trades (on a job site) into a single unit for purposes of collective bargaining. \& The CBC wanted floor managers and stagehands included in the NABET unit in order that all employees working on stage should belong to the same union. This would have eliminated jurisdictional disputes during rehersals and avoided the clumsy arrangement whereby the CBC producer of ten has members of five different unions working together on stage $\gg$. In the course of a typical program, there are only two ${ }^{9}$ unions with members on the floor: NABET (technicians) and IATSE (production) ${ }^{10}$. One wonders, in view of this, why there «too many unions»?

8 The apportioning of the advertising cost burden depends on the price elasticity of demand of the advertised product. The greater this elasticity, the higher the proportion of advertising costs borne by firms and vice versa.

9 This excludes actors and musicians whom the CBC could not possibly (for historical reasons) have lumped together in a single union anyway. IATSE.

0 At the time the book was written, the CUPE members were represented by 
The real locus of the problem lies at the level of job classification within unions, even within a single bargaining unit! The « jurisdictional disputes $>$ alluded to in the quote really occur between, for example, the floor manager (IATSE) and stagehand (also IATSE), or between different types of stagehands, or between a stagehand and a decorator (IATSE), all in the same unit! The IATSE unit in Montreal contained no less than 49 job titles! Each of these «trades 》 had a written job description and each group was, understandably, extremely sensitive to others trespassing on its job duties. This is simple Perlmanian « job consciousness $\gg$ 11. You protect your existing and future jurisdictions (job duties) and you assure the continued existence of your job. When a member of one trade trespasses on another's jurisdiction, the latter reacts as violently as if the attack it had been made by someone from a different unit or a different union! One filed a grievance irrespective of whether the violation came from a * brother or not.

The attitude and reaction described above carries an important lesson for those seeking to bring order to the chaotic industrial relations in the beleagered construction industry ${ }^{12}$. The solutions to inefficiency and interunion strife seem all to be directed at enlarging the bargaining unit. While this may appear to be the reasonable line of attack, our analysis of the TV stage seems to suggest that the real answer lies elsewhere. Occupants of each job classification are gardians of their collection of duties and will, in self-defence, react fiercely to any attempt to erode those duties. The situation is not entirely unlike the behaviour of oligopolists as described in intermediate microeconomic texts. Each member wants the industry (unit, union) to grow but also wants at least to maintain his market share (i.e. job). The lesson derived from this digression is that only restructuring the work processes themselves and by, in the case of construction the trades, can we hope to reduce jurisdictional tensions substantially ${ }^{13}$. To be sure, it is no simple matter to restructure the job tasks (acts). But the remedy for the frictions does appear to lie in making tasks broader and more flexible ${ }^{14}$.

Directing policy at the unit and union levels reminds one of the naive approach to reducing labour-management conflict as expressed

11 Selig Perlman, A Theory of the Labour Movement, MacMillan, 1928.

12 Symptomatic of growing concern are the Goldenberg-Crispo Ontario Royal Commission, the recent Quebec laws, the Woods Committee in Nova Scotia, the Saskatchewan and Alberta experiences.

13 It is true that by marging 《units these levels may recede (though there may still be «cliques》 within the enlarged arrangements). The really fundamental problems is the job jurisdiction and no agrandisement of the units or unions will solve this problem.

14 William Gomberg believes that these work rules are no more inefficient that other arrangements which are socially accepted. See his intreging, «Feather bedding : An assertion of Property Rights $\gg$, in M. Wortman, Critical Issues in Labor, MacMillan, N. Y., 1969. 
by the (growing) group of Industrial Relations Astroligers. To eliminate industrial conflict you simply pass laws outlawing strikes. These "experts 》 act as though strikes were the only costly expression of worker discontent as that wildcat strikes did not exist. You do not cure visible cancer sores with iodine and band aids!

While in the area of the CBC unions, there is an incident that occurred within IATSE which should be written into the record. At a meeting of local 878 stewards in 1963, it was decided that, since $98 \%$ of the 600 members were French-speaking, quarterly membership cards should be in the French language. When the next batch of cards came in from New York, these were returned with an appropriate explanatory note. Some time later the same cards arrived without explanation. Our business agent, Yvon Dansereau, communicated again with the head office, asking that the "French Fact 》 be respected. He was summarily advised that cards were always printed in English and that there was no possibility for change. A further suggestion that, for convenience, cards be printed here with the bill sent to headquarters fell on deaf ears. One wonders if the new CUPE unit has acceded...

The section on IATSE (p. 41 sq.) must really be brought up to date even if only in the briefest of terms. CUPE was finally able to replace IATSE and by successfully defeating the SGCT (CNTU) attempts to split the 1600 members national unit. It seems, however, that those Montreal members of the unit who still retain their links with the SGCT have not given up their fight for a separate Quebec unit ${ }^{15}$. Though this reviewer's own feelings in this area are now well documented 16 a further comment might be in order here. One questions the wisdom of the position taken by the CLC executive in maintaining, beyond all common sense, the «jurisdictional monopoly " principle. Their lack of courage and foresight, their imposition of the IATSE union on an unwilling membership for so long created a great deal of unnecessary animosity not only towards the CLC, but indeed towards the very idea of unionism itself. There was, for example, the callous treatment given to the short-lived, but grass roots supported, Canadian Television Union ${ }^{17}$.

It might have been useful to have mentioned that the clerical union, ARTEC, grew out of the paternalistic «staff councils 》 and was regarded by other unionists as something only slightly more than a «company union ». Aside from its pedigree, ARTEC was the only union without

15 Based on conversations with those involved, January 1971.

16 See B. Brody chapter : « The Bargaining Unit for Quebec », in E.E. Flerman, The Size and Composition of the Bargaining Unit, Task Force on Labour Relations, Ottawa, 1969.

17 The CTU lost its 1965 bid for certification when the Canada Labour Relations Board (CLRB) rejected an application on what really amounted to a technicality. 
CIC affiliation. Also, its character is revealed in its lack of solidarity with fellow-unions and failure to hold out for more than two weeks during the 1959 producers' strike ${ }^{18}$.

As pointed out at the outset of this review, Miss Samlalsingh's study terminates at an unfortunate time. Subsequently, the efforts to fractionalize the IATSE national unit created what is undoubtly the most heated controversy in the history of the CLRB ${ }^{19}$. The CNTU did indeed withdraw all its representatives from all federal bodies. Only when the government presented Bill C-186 ${ }^{20}$ late in 1967 did this federation's relationship with the government return to normal. ways :

Bill C-186 was to have amended the IRDIA in three important

1 - The single CLRB would sit in several regional divisions. This would have removed it (at least partially) from its secluded Ottawa ivory tower and brought it closer to where the action is, into the mosaic of rapidly changing social realities within this diverse nation of ours. Members would obtain a more realistic «feel » for regional diversity and thus be better able to respond in a more coherent and positive way.

2 - The new law would state explicitly that the board could take into account regional peculiarities as a criterion for determining if a proposed unit is appropriate. The IRDIA does not of course address itself at all to this question 21 . It was the board's own extensive jurisprudence favouring national units and its almost fanatical reticence to split an existing national unit that blinded it from seeing the obvious regional forces for change.

3- An appeal procedure was to be established when the board refused a regional unit. This was the weak substitute for a specific change demanded by the CNTU 22 .

In cases where there was a jurisdictional dispute involving a CNTU union and a CLC affiliate, the board, as presently constituted, can hardly tender equitable justice. Of the four employee representatives on the board, three have CLC affiliations, only one is nominated by the CNTU ! The defunct Quebec Labour Relations Board used the formula of divesting

18 Some of the issues surrounding the strike are discussed below.

19 See B. Brody in E.E. Herman, op. cit.

20 See CNTU, Memorandum to the Federal 'Cabinet, February 16, 1966, esp. pp. 26-27 for this federation's proposals for «urgent amendments 》 to the IRDIA (the federal labour act).

21 The IRDIA only asks that the unit be «appropriate for collective bargaining 》. Article 8 does indicate some a priori appropriateness for «a craft or group exercising technical skills $\gg$.

22 See footnote 19. 
all members - except the chairman - of voting rights ${ }^{23}$. One takes serious issue with Miss Samlalsingh when she state (P. 52) « ... the disparity in the size of the two labour organizations ... (CLC, CNTU) ... would justify greater representation of the CLC ». While this quantitative justice applies to all other matters handled by the board, it could not be seriously sustained in cases concerning inter-federation jurisdictional disputes. An important principle of democratic justice is that one cannot be both party and judge in the same case. It should be noted that the CLRB did indeed split a national unit at the CBC shortly after the tremendous uproar it created in the event described in the previous paragraph. It decided to grant a Quebec, carved-out unit to the SGCT from within the national CWSG. One of the board's criteria for «appropriatness $>$ in this case was the discernable language and cultural identity of the CBC-Newsroom employees in Montreal, Quebec City and Chicoutimi. This is essentially the same argument (among others) used when SGCT applied for, and was categorically refused a certificate for the Quebec IATSE members ${ }^{24}$.

A single (to this reviewer's knowledge) adverse incident did arise from the split when the Toronto TV newsroom temporarily refused access to a Montreal-based reporter, member of the break-away group.

The CLRB «no-fractionalizing 》 rule was obviously an over-worked, archaic doctrine. It was maintained and imposed mainly because it constituted a comfortable bit of dogma and relieved the tired board members of the need to engage in the necessary intellectual and practical exercise of dealing with the new realities of the new Canada. I remain convinced that even though the ex-IATSE case is now "closed > 25 , the CUPE national unit solution is not a final answer.

There is nothing either in law or in jurisprudence obliging the board to judge as to the relative appropriateness of two possible units. It is not required to look to the "most appropriate 》 one. Perhaps the «most appropriate unit» is one composed of all the unionizable employees in

23 See CRT, Amalgamated Lithographers, loc. 27, vs. Montreal Printing Pressmen, loc. 52 et Montreal Typographical Union, loc. 176 and Mercury Press ; August 22, 1966.

24 In the Brody chapter (E.E. Herman, op. cit.), it was argued that the cultural identity, butressed by the strong will expressed by the workers involved should been sufficient for a Quebec unit to qualify as «appropriate ». There was and still is almost no mobility (transfers, etc.), between the members involved in Quebec and those in rest of Canada. Surely this is an important constituent of «community of interests 》, the principle on which «appropriateness veniences 》 to management remains a second order objection.

25 Very recent (January 1971) conversations with both, $\mathrm{CBC}$ management and various union representatives indicate that the regional tensions have still not subsided significantly. 
the Quebec division. With a carefully laid out structure which guarantees autonomy to the various classes of workers (approximately equivalent to the existing unions) the split would best serve the interests of both the $\mathrm{CBC}$ administration and the union members. An alternative suggestion would be coalition bargaining by existing unions, but for the Quebec division separately. Surely this reduction in the national sweep would allow collective bargaining to cope much better not only with economic issues (being based on the economic realities of the region) but also with those very important specific political and cultural realities. It is perfectly naive to pretend that one can compartmentalize these political and cultural forces out of the economics and sociology of the work place.

\section{The OUTPuts OF THE SYSTEM}

Under the subtitle «Institutionally Oriented Outputs » (p. 71) one is surprised to find the discussion limited to the unions and their members. Surely the corporation is as much an «institution », and surely « managements rights $\gg$, problems of dealing with so many unions and regions, etc. constitute appropriate and important outputs.

The relative wage in broadcasting is ascertained by comparing it to that of manufacturing (p. 73), and the former shows a favourable differential. This exercise reveals the bias of using « averages ». Would it be of any significance to learn that, at the time of the producers' strike there were full-time adult employees in the IATSE unit union with gross weekly wages of $\$ 44.04 ? 26$

Another output, technological change, is dealt with summarily. The repercussions of technical change in broadcasting have become even more dynamic since the publication of the book. As this review is being written there are sweeping spatial consolidations taking place both in Montreal and Toronto. The multi-million dollar Montreal complex covers several city blocks in the eastern part of the city. The new quarters will the most up to date anywhere and new equipment will render many existing skills (especially technical skills) obsolete. There will be labour-reducing innovations on the production side and for operator-technicians (e.g. camera controls, master controls, téléciné-projectionists). Some of the latter are now being retrained as maintenance technicians to meet the increased need of this skill. Master control will be wholly computerized, with the entire day's station breaks and cut-ins programmed onto magnetic tape each morning.

It will be interesting to observe the way all concerned ajust to resolve the inevitable tensions and conflicts that accompany so rapid and extensive a change in the work situation.

26 CBC/IATSE, Collective agreement, 1959, p. 32. 


\section{The Talent Unions}

Miss Samlalsingh was surely carried away when she wrote (P. 82) «By sheer weight of their organized strength they... (the CBC-TV producers) ... have been able since 1959 to force voluntary recognition by the employer $\gg$. These 74 producers had, it must be remernbered, the full-force backing of $1800^{27}$ fellow workers as well the CNTU, the QFL, the artists and the authors ! Without the voluntary support at very great personal sacrifice ${ }^{28}$ - of these 1800 , the producers would still be picketing outside the Dorchester CBC headquarters today!

The type of "agreements » reached by the CBC and its talent unions, AFM and ACTRA ${ }^{29}$, takes us back into the history of wage theory. These unions bargained not only for a wage rate, but also for a guarantee of a certain proportion of the company's total expenditives : a «wage bill». For the musicians, this was $35 \%$ of total talent fees, for the actors it was that at least $\$ 15$. million was to be spent on talent fees. Could this throw back to the defunct (?) «wages fund theory 》 offer any useful insights on how to solve some of the conflicts concerning job security and job guarantees? Could we apply the wage bill concept to help find solutions to the ever-growing cases of mass lay offs currently buffeting the Quebec economy?

There is also potential profit to be gained from a deeper examination of the CBC-ACTRA arrangement in providing a union steward for every show in which an ACTRA member performs. The steward's fee is shared equalilly by union and employer. This is one of the very problems that has kept the Quebec construction industry in a state of termoil for the past year. Is a shared-cost plan the solution here too?

\section{The Producers Associations}

In this chapter on the controversial Montreal CBC-TV producers Association and their strike the author again reveals her outstanding ability in the research art. Most of the major events and much of the fine detail in faithfully described in her book.

There are some matters, however, which it is virtually impossible to discover unless one has lived through them. It is the task of scientific

27 Includes ARTEC, who went in after about two weeks.

28 Some of the strikers lost homes, autos, health, marital stability. Many accumulated large debts. At an average weekly wage of $\$ 85.00$, the staff support group lost a total income of over one million dollars! The loss of the free-lance supporters - actors and authors - is difficult to estimate and is not included in this total.

29 AFM, American Federation of Musicians ; ACTRA, Association of Canadian Radio and Television Artists. 
research to seek causal relationships between events and variables. This is usually carried out in abstration, for example, of the decisive role often played the personalities involved ; personal friendships and personal antipathies. Many of us close to the 1959 producers' strike felt, for instance, that things might have developed differently had the then-Director of CBC-TV in Montreal not been the younger brother of the President of the CBC. Again, could a researcher have discovered that the multitude of films used by the CBC to cover the 69 day strike were rented from the same individual who was shortly thereafter to be awarded the franchise for the private French TV outlet in Montreal, and that, almost to a man, the Montreal CBC-TV management staff (including its Montreal Director of TV) was to leave the Corporation and manage this new, rival station?

Based on producers' opinions, the author states (P. 93) that the major cause of the strike was that producers felt «.... their function had changed considerably since $1953 \gg$ by gradual removal of most of their «management duties ». She goes on to quote (P. 96), «we would be willing to give up any pretentions to management functions in order that our syndicat be recognized ...». Firstly, on the basis of this reviewer's experience, the alleged significant removal of the producers management function is quite exaggerated. Though there was some erosion, it had not seriously hampered their ability to work property.

In looking back from the vantage point of the past ten years, the main cause of the strike appears quite certain to this reviewer. Management had failed to develop the required level of administrative competence that was necessary to cope with the rapid transition of the operations here from a cozy, paternalistic and intimate environment, into a vast and complex enterprise employing a thousand artists and scientific and technical specialists. The breakdown of personal, vertical relationships was generalized, profound and evident to all. There was no confidence left in either direction; up or down. Management had become sloppy and unprofessional in its dealings with producers. The contract renewal mess is typical of this gross incompetence. There was almost no job security for producers because so many individual contracts had run out. In retrospect then, this is a classic example of a firm outgrowing its owner's capacity to manage things. Had the operations been based on profitability, the enterprise would have folded up before 1958.

Secondly, I would seriously question the contention that the producers were willing to give up any significant management functions in exchange for whatever job security a collective agreement might bring. I base this position on two arguments :

1 - It is not really possible for a producer to be creative, i.e. exercise his art, if he cannot choose his own scripts, performers, musicians, decorators, rehersal length, etc. When, following the strike, the CBC interposed between the producers and his «cast 》 (against the will of the producers) the «unit administrator ${ }^{30}$ a new bureaucrat - the producer really lost control of his art form. To illustrate, say a produ- 
cer feels that, for the show he has in mind, the ideal singer is Miss Alpha. Miss Alpha asks $\$ 1,000$. for her performance. The producer then submits this expense item to the unit administrator. The latter now has the power to refuse the request and to recommend Miss Beta, also a singer, who is ready to do the show for $\$ 750.00$. It is thus obvious that the right to hire a performer of his taste is an important aspect of the producer's ability to create a show. To divest himself of this right in to emasculate his function.

2 - A few years following recognition of their association, the producers lodged a formal complaint with the Board of Broadcast Governers stating that the Corporation had removed some important elements of their management duties and it was therefore impossible for them to function properly.

This apparent incompatibility of management responsibility with job security and unionism raises one of the most burning issues in contempory North American Industrial Relations : supervisory unionism.

Supervisory employees ( les cadres $»$ ) want to retain the prestige and power, but also want more job security ${ }^{31}$, a grievance procedure with ultimate third party adjudication. They want replacement of the authoritarian regime within the firm hierarchy by a more democratic process. Can they have both ? Can top management find a way of introducing the basic tenents of industrial democracy into an establishment which has never denied its essentially undemocratic ideology? Is it possible to reconcile absolute power, democratic values, and job security? Is top management prepared to accept the obligation of showing \& just cause » for firing or accepting third party arbitration in disputes with lower and middle management staff ? This reviewer remains essentially optimistic on the capacity of existing organizational mores to adapt to the challange of what seems to be a growing feeling of the need for collective self-protection. The propensity to seek such protection by employees who have traditionally considered themselves secure (providing they did their jobs properly) will increase as organizational, technological and economic changes intensify. In the world of the 1970's all indications point to an acceleration of such changes.

To date top management has reacted emotionally, and removed some discretionary power from supervisors. This tendency of moving the locus of effective power higher up in the organization is undesirable because it enlarges the distance between the decision - makers and those who live with the effects of decisions. Top management must learn to

30 This administrator is a type of cost accountant or comptroller.

31 Executive lay off and professional unemployment are becoming common; viz., Air Canada in 1970, etc. See Financial Post, January 23, 1971, p. 1 : « Job Squeeze Hits Executive Suites... 
respond in a more rational way and with the best interests of the organization as its criterion ${ }^{32}$.

\section{PRODUCER AFFILIATION}

There is one burning question which the book fails to answer or indeed to raise. Why was the CBC management so adament and inflexible in its absolute opposition to the affiliation of the producers' Association with the CNTU? We are informed, in vivid terms, of the alterations in the wording of the terms of agreement ending the producers' strike and how the association moved away from outright affiliation to a much looser arrangement involving the supply of «technical services». We are also told that disagreement on this subject kept the 1200 strikers out for an extra week. Why did the CBC hold up settlement and re-integration of the strikers on this seemingly technical and really marginal point? After all, the other CBC unions possessed this freedom and were all affiliated to a federation, the CLC ${ }^{33}$. Could there have been a " conflict of interest 》 between «managed * and * managers $>34$ belonging to the same federation?

One would easily concede a high probability of conflict of interests where managers and managed share a single bargaining unit. This concession is slightly less forthcoming when there are two separate units within a single union, but here too there is much room for potential conflict. However when the only source of possible conflict resides in the common affiliation to a federation of two wholly independent unions, the opposition must be disgarded ${ }^{35}$.

Furthermore, it must be remembered that this was a case of voluntary recognition by a single employer. If it had been a request before a labour relations board for a certificate, formal considerations of the appropriateness of the affiliation might have been more necessary because of the jurisprudence it might have created.

In any case, there were no employee unions affiliated with the CNTU at that time anyway, so even this could not have been the real reason for CBC's opposition. What then was it? We can only speculate. Was the arrangement singled out because it would have given the CNTU

32 At Université de Montréal, a M.A. thesis is currently being directed by the reviewer on the effects of this type of unionization.

33 Although ARTEC was unaffiliated to the CLC, it was in the stages of merger with NABET which was affiliated.

34 See below for a fuller explanation of this «manager-managed relationship.

35 Shirley Goldenberg, in Professional Worker and Collective Bargaining, Task Force Study No. 2, 1970 holds that «while some prophets of doom deplore the possibility of union affiliation... (for professional unions) ... in my opinion this is not a major problem $>$ (p. 99). 
a foothold among federal government employees? Was the CLC monopoly at stake? Did the government want to avoid the discomfort of interfederation rivalry? Was the government afraid that the CNTU's millitancy would spread to the picnic-oriented associations which represented the civil servants?

Or was the CBC the subject of pressures from employers, through the cabinet, who did not want to create a presidence in the area of supervisory unionism in North America ? Only the CBC top management know the true answer or the correct combination of those presented here.

On the subject of the extent and quality of the producer's managerial powers - a very critical issue indeed - Miss Samlalsingh is less than fully correct. She writes (P. 101), « The solidarity of all categories of employees with the producers who exercise managerial control over them was remarkable» (ital. added). The facts are these : TV producers exercise managerial control only on the talent union members (actors, writers) who are all free-lance thus not $C B C$ «employees 》. The 1200 support strikers - 650 IATSE (production crews) 450 NABET (technical crews) and 50 CWSG (newsmen) - were all CBC staff employees. The work relationship between a show producer and the crews is devoid of vertical managerial power. Each of the former categories has a line supervisor for every show who possesses these rights ${ }^{36}$. Thus there is a chief accessory man, a technical producer, a newsroom supervisor. The producer asks for specific acts from crew members which are in harmony with his conception of the image content he wants to project on home TV screens. He has nothing to do with the management of the employees in the sense that he goes not $" \ldots$. represent the employer in his dealings with the employees ${ }^{37}$. This is the essential but subtle distinction that must be made between someone who supervises the work of others and someone who supervises others. An organizational chart of the CBC hierarchy would not show any solid vertical lines linking the blocks marked «TV Producer» and «TV Cameraman». There would be such link between «Technical Producer » and «TV Cameraman ». There would be none between «TV Producer» and «Technical Producer ».

The first part of the quotation, the « remarkable " support received by the producers is intriguing for a variety of reasons and it is of immense importance that other industrial relations researchers be made aware of the facts in this particular case.

On the basis of his own twelve (12) years TV studio experience, this reviewer contends that most of the 1200 supporters actually disliked

36 Though this is not the place to enter a full discussion of what constitutes «managerial rights $»$, the reviewer's opinion it that they center about the rights to hire, fine, discipline, merit rate and similar powers.

37 This is an accepted meaning and a reason for excluding an individual from the definition of \&employee $»$ in the IRDIA, s2 (1) (i) (jj). 
most of the producers. The producer's function is to create, and he thus exposes his tastes (or lack of them) when he asks tasks of the technical and production crews. Anyone with professional stage experience knows the disdain with which most artists hold other artists. TV crew members constantly criticize producers for the alleged stupidities and maladroitness exhibited in their shows. Adding fuel to this perception is the existence of the unusually extensive practice of nepotism in the industry. "One day he was an insurance salesmen, the next day be began ordering us about the stage just because his uncle is ...».

Whether most of the producers were actually inept and lacked «taste » is of course irrelevant. What matters is that this is the way the crews perceived them. How then do we explain ${ }^{38}$ the support, at great personal sacrifice, of the 1200 ? Miss Samlalsingh (P. 101) offers several explanations ; all falling, more a less, under the general rubric : "Nationalism » ${ }^{39}$. They are : (1) rejection by English CBC locations of support for their French fellow unionists ; (2) rejection by the Anglophone Prime Minister and Labour Minister of requests to intervene and force the CBC management to settle; (3) rejection of the merits in the case by the Montreal Anglophone press.

To these, the reviewer adds : (4) Most Montreal CBC-TV workers felt a contempt towards the local management. This made for a feeling of solidarity when the producers decided to «stand up 》 against them. (5) Right from the start of the strike, all supporters were subjected to what came to be known as «booster shots ». These were weekly meetings and ralleys which were always highlited by outbursts of masterful oratorical gems by such well-known (and loved ...) figures as René Lévesque, Jean Marchand, Jean-Louis Roux, Louis Morriset, Jean Duceppe, etc, This was not a strike led by manual tradesmen. These strike leaders were familiar French Canadian personalities, held in high esteem and supurbly gifted in their common art and source of livelihood: the technique of emotional seduction. (6) As stated above, the studio crews did not think too highly of most of the producers, yet they did support them. This seeming paradox requires a specific explanation beyond that supplied in this list thus far. To make this point understood, it is necessary to reconstruct the environment of a TV production studio with a show in progress. The production process itself calls for an extremely high degree of integration and interdependence of personalities. It takes a sense of belonging to a unified, single entity. There exists a certain, almost mystical bond among all participants, in front of as well as behind the cameras.

38 These explanations will apply to pre-strike motivations as well as those manifested during the period the supporters were actually out. They seek to explain not only why they went out, but also why they held out.

39 On this barely pre-« quiet revolution » era, one is led to speculate on the character of this nationalism. It appears to have been of the older variety, almost \& racism \$, in the sense that it was exclusively anti-English, rather than pro-French. 
The «support paradox» should thus appear as something akin to the relationship between two neighbours who «hate o one another. In a moment of crisis (a fire) however, the familiarity of closeness seems to come to the surface and makes itself felt in support action. (7) The strikes were told repeatedly by some leaders that there would be no pay lost over the strike. The CBC was acting illegally and they would pay for the strike. Well known actors and personalities told us about the «secret talks », usually held « just a few minutes ago » with «an influencial member of parliament» who said that this was so. Under these terms, the supporters reasoned, why not «take time off 》 at the company's expense? In the end the strikers were bitterly deceived (by their leaders ? by the M.P.'s ?). The corporation was not strictly « illegal » and they paid nothing. To add insult to injury the strikers were obliged to make up the missed payments on pension plans, etc. (8) There was a rather hazy « right » being defended « the right of association». This slogan was repeated over and over again until it was imprinted on the strikers' brains. Almost no one ever bothered to explain what it meant, very few ever sought its meaning. It sounded like something sacred and inalienable and thus was «worth fighting for ...». The reviewer recalls his own flamboyant outbursts during the demonstration in front of Ottawa's parliament buildings : "Give me liberty or give me death 》. (9) The strike coincided with the Christmas holiday season. There were the usual parties help during the previous week and a quasi-carnival atmosphere prevailed. Why not just extend the holiday ... especially for those who were scheduled to work.... (10) Even before the strike actually got under way (midnight, December 29, 1958) union leaders had convinced the workers that the CBC would not, could not let it happen. But even if they were so foolish as not to heed the producers' legitimate demands, the French network could not possibly hold out for more than a couple of days. The passing of the midnight deadline injected a dimension of stark reality into events ... Before we knew it, and without any effort on our part, we were actually on strike. One had the feeling of floating without any links to anything solid ... something like the first seconds of a parachutist's free float from out of the plane's fuselage ...

As the days wore on without any signs of weakening by management, the «extended holiday 》 took on a more somber colour. We began to miss our paychecks as the bills kept coming in ......

There are three other aspects of the « remarkable relationship 》 which should have acted against the above list and perhaps even nullified the support of the 1200 for the 74 .

1 - All the existing unions at the CBC were CLC-affiliated ${ }^{40}$, the Producers' Association was working with the rival CNTU.

2 - Most of the producers had incomes approximately twice those of the average support group members. This reviewer, in the highest

40 See footnote (31) re: ARTEC. 
IATSE classification was earning less than $\$ 5,000$. while a producerfriend (with only two more years of service) received $\$ 12,000$.

3 - The Quebec unemployment rate in October - November - December 1958 was in the order of $10 \%$. The possibility of finding a part time job during the strike ${ }^{41}$ was remote.

It is now incumbent upon the reviewer to explain why the 1200 did risk so much. The simple (simplistic ?) explanation is that the sum of the cohesive, centripetal forces of the first list (1-10) exceeded the sum of the divisive centrifugal forces of the second list (1-3).

\section{OTHER ISSUES}

The author states (P. 106) «... (the producers) ... got a collective agreement covering general working conditions and setting basic scales, and in addition gained the privilege of negotiating individual contracts for rates of pay over and above the collectively agreed scale ... ». « This is an usual combination of employment arrangements ....». (ital. added). But surely this is not an «unusual» arrangement. I have never seen a collective agreement where salary scales were anything but minima.! Would any union ever handicap its members by imposing maxima? Would any employer limit his ability to retain and recruit individuals who command above-scale wages? All a union really wants is to ensure that there is no undercutting : downward inflexibility. Some introductory labor economics texts give this erroneous impression : that unions hinder members' personal wage opportunities by setting out inflexible wage scales. Nothing prohibits the employer from granting above-scale rates.

\section{FreEdom of Association}

I must also take serious issue with Miss Samlalsingh's statement (P. 106) : "Is there a case for enlarging the scope of the law to cover these excluded categories ... (lower level management ?) ... or should the existing structure be maintained so that only the bold and fearless may wrest the benefits of bargaining through the strengh of thier collective action ». The author is overly-generous in her evaluation of the sources of power in this case. I must again correct the impression one gets from the book about the «Batman »-type « hero power » of the 74 producers. The bulk of the power came from the 1200 support army. Of the dozen or so recognized strike leaders, the reviewer can think of only one producer. Miss Samlalsingh reiterates this myth again on P. $110 \ll \ldots$ by sheer force of their ... (the producers) ... organized strength 》.

We now turn to the question of freedom of association and the exclusion of supervisory employees from the IRDIA. Among others, the

41 Economists look to the unemployment rate as one of determinants of the propensity to strike. In this case the factors in the first list were so pervasive that the « alternative employment principle - probability of supplementing lost income - was for all practical purposes, totally irrelevent. 
Quebec Labour Code, the Civil Service Act and the Federal Public Service Staff Relations Act do not exclude these classifications. I do not believe it equitable to withhold the right of association from any group of employees. It should be available to all, the implementation of that right would depend upon and be the primary concern to those directly involved. The Woods Task Force ${ }^{42}$ states that the exclusion of supervisory and junior management employees is unjust and recommends that access to collective bargaining be permitted to them. The (overdue) new Federal labour statute should recognize the new realities of the sociology of the firm and also reflect the changes in social values since 1948.

No group of workers should be forced to make the kinds of sacrifices made by the CBC strikers in order to forge new laws. Let us hope that, by 1971 , we have learned to minimize the cost of achieving social justice. The fundamentally masochistic and perverse value that is somehow 《good $\gg$ or « just » for one to suffer in order to have his rights recognized must surely be relegated to the garbage dump of history. Laws should be, though unfortunately rarely are, forward-looking. Lawmakers should be, though unfortunately rarely are, able to see ahead and estimate the kinds of laws best suited to regulate affairs among citizens (and between citizens and the state).

\section{Producers as « Professionals 》}

Miss Samlalsingh states (P. 113), «The real ... (strike) ... issue was the criteria for defining the management function. The matter of their ... (the producers) ... professional status was never in question. Under the Act, producers would have been excluded from Union affiliation on both these scores ». The last statement is surely erroneous. Producers do not qualify as «professionals » under IRDIA 2(1) (i) (ii) any more than do economists, archeologists, chemists or university professors. They have no corporation with authority delegated by the state for regulation of the affairs of their profession. Even using the much broader sociological definition of a «professional », TV producers do not fit in ${ }^{43}$.

\section{Et Cetera}

One of the main shortcomings of the book is its very summary treatment of one half of the Broadcast industry: its private sector. This

42 Op. cit, p. 139.

43 See H. L. Wilensky, «The Professionalization of Everyone?» American Journal of Sociology, September 64, pp. 137-58; and G. Strauss, «Professionalism and Occupational Associations », Industrial Relations, May 1963, pp. 7-31; and S.B. Goldenberg's, Professional Workers and Collective Bargaining, Task Force study \# 2, chapters one and four offer a very competent discussion on the meaning of «Professionalism», the location of the professional within the firm, and professional collective bargaining experience. 
is especially true of labour relations there. Granted that data is difficult to come by some theoritical issues could have been explored. Why is unionization low among private station employees? Turn-over rates are very high, units are small, ownership changes hands frequently. Why high turnover rates? Newcomers, both on the announcer side as well as in engineering (operations) often use a low paying private station job as a stepping-stone to the $\mathrm{CBC}$ or to the USA. There are a large proportion of «transients ». An analysis of CBC-employee work histories will reveal this strong flow from the private stations. Because of the nature of the work (and the resultant nature of the employee) a dissatisfied private station employee chooses to change jobs rather than stick it out and unionize to ameliorate conditions. The stations with unions are invariably the larger ones where employees look to long run careers and so have a stake in the type of working conditions that evolve and prevail. If the cabinet deems that it is in the public interest to improve working conditions 44 then there exists a mechanism with which to bring this about. The Quebec Collective Agreements Act provides for « juridical extension » of a single collective agreement to an entire industry or to an entire region. It would thus be unnecessary to obtain bargaining certificates for each station (a very highly unlikely situation), and the extended conditions become legal minima for the employees concerned.

Name errors are analytically insignificant, but can be irritating. So we read "Canadian National Trade Union» (P. 46) and "Canadian National Trades Union» (P. 32) for the «Confederation of National Trade Unions », Canada's GNP comes out as $\$ 176$ billion (P. 16) when it should have been $\$ 76$ billion(?). Several references to IATSE local 874 are made. The Montreal local of IATSE operating at the CBC was local 878. On page 6 , we read that beer advertising on TV is prohibited in Canada. Since when does Molsons make lemonade?

History will be grateful to Miss Samlalsingh for her excellent contribution to a better understanding of industrial relations in general and in this spectacular industry in particular. Broadcasting - An Industry Study joins two existing works on the era and events : Jean Louis Roux's, "Radio Canada 》, chapter in En grève ${ }^{45}$ and the reviewer's own chapter in Herman's bargaining unit study for the Woods Task Force (see footnote 15). The reviewer hopes that his present effort also fills in some of the gaps in the story.

44 Station owners know that most job candidates are looking to move on elsewhere and therefore offer low salaries and long hours. The reviewer is aware of one station where announcers receive no salary at all! Compensation is limited to « experience $»$.

45 En grève, Éditions du Jour, 1964. 